\title{
PENGEMBANGAN VIDEO ASAM BASA BERBASIS LINGKUNGAN UNTUK MENINGKATKAN PEMAHAMAN SISWA KELAS XI
}

\section{Development of Environment-based Acid Base Video to Increase Class XI Students' Understanding}

\author{
Dewi Handayani Rina Elvia, Mia Maysella Aditia \\ Program Studi Pendidikan Kimia, Fakultas Keguruan dan IImu Pendidikan Universitas \\ Bengkulu \\ Gedung Dekanat FKIP, JIn. WR. Supratman, Kandang Limun, Bengkulu, Indonesia
}

\author{
Muzanip Alperi \\ LPMP Provinsi Bengkulu
}

Jln. Zainul Arifin No. 2, Singaran Pati, Bengkulu, Indonesia

d.handayani@unib.ac.id

\footnotetext{
Diterima:

19 Agustus 2019

Direvisi:

25 Mei 2021

Disetujui:

08 Juni 2021
}

\begin{abstract}
ABSTRAK: Pemahaman siswa terhadap konsep materi asam basa masih rendah. Hal ini ditunjukkan dengan masih banyaknya siswa yang belum mencapai kriteria ketuntasan minimal (KKM). Pemahaman konsep dari siswa yang masih kurang ini disebabkan oleh belum adanya penerapan konsep yang tepat, efisien, dan akurat dalam memecahkan masalah. Salah satu solusi yang diberikan adalah penggunaan video pembelajaran berbasis lingkungan. Pengembangan video pembelajaran berbasis lingkungan ini dibuat agar siswa menjadi lebih tertarik dan senang belajar. Dengan demikian, siswa lebih mudah memahami konsep asam basa. Penelitian ini bertujuan untuk mengukur pemahaman konsep siswa kelas XI IPA di SMA Negeri 03 Bengkulu Utara. Penelitian ini menggunakan model pengembangan Four $D$ yaitu pendefinisian, perancangan, pengembangan, dan penyebarluasan. Namun demikian, pada penelitian ini, tahap penyebarluasan tidak dilakukan. Populasi dalam penelitian ini adalah seluruh siswa kelas XI IPA SMA Negeri 03 Bengkulu Utara yang berjumlah 100 orang. Sampel yang didapat dari uji normalitas pada uji coba skala kecil terdiri atas 12 siswa di kelas XI IPA 4 dan uji coba skala besar terdiri atas 25 siswa di kelas XI IPA 1. Data penelitian ini diperoleh dari hasil soal tes uraian untuk mengukur pemahaman konsep siswa. Hasil penelitian menunjukkan bahwa video asam basa berbasis lingkungan dapat meningkatkan pemahaman konsep siswa, yang tergambarkan dengan peningkatan persentase nilai rata-rata sebesar $88,8 \%$ dengan "kategori baik sekali".
\end{abstract}

Kata kunci: video pembelajaran, berbasis lingkungan, pemahaman konsep, asam basa

ABSTRACT: Students' understanding on acid-base concept is still low. It is indicated by high number of students who have not reached the minimum completion criteria (KKM). The students' low understanding is caused by the fact that there has not been any proper, efficient, as well as accurate concept application to solve 
problems. One of the solutions is the use of environment-based learning videos. Environment-based learning video is made to make the students more interested and happier to learn. Therefore, they can understand the concept of acid-base more easily. The aim of this research is to measure the understanding on acid-base concept of class XI IPA students in SMA Negeri 03 Bengkulu Utara. This research applies Four D development model, i.e. defining, designing, developing, and disseminating. However, this research doesn't go until "disseminating". The population of this research is all students of class XI IPA in SMA Negeri 03 Bengkulu Utara amounting of 100 students. Sampling is from normality test to small scale trial, i.e. 12 students of class XI IPA 4 and big scale trial, i.e. 25 students of class XI IPA 1. The data of this research is from the result of essay question test to measure the students' understanding. The result shows that the use of environment-based acid-base video can increase the students' conceptual understanding, indicated by the increase of the students' average score of $88,8 \%$ which belongs to the category of "very good".

Keywords: learning video, environment-based, conceptual understanding, acid-base

\section{PENDAHULUAN}

Perkembangan ilmu pengetahuan dan teknologi saat ini telah membawa perubahan yang sangat pesat pada semua aspek kehidupan manusia. Salah satu aspek yang mendapatkan pengaruh dari perkembangan ilmu pengetahuan dan teknologi adalah dunia pendidikan. Pendidikan merupakan upaya yang terencana dalam proses pembelajaran bagi individu agar berkembang dan tumbuh menjadi manusia yang mandiri, kreatif, dan berilmu (Inanna, 2018).

Penggunaan media dalam proses pembelajaran di kelas merupakan sebuah kebutuhan yang tidak dapat diabaikan. Media pembelajaran juga merupakan salah satu pendukung yang efektif dalam membantu terjadinya proses belajar yang dapat menyalurkan pesan dari pengirim ke penerima yang mampu merangsang minat, perhatian, dan motivasi siswa dalam kegiatan pembelajaran (Mahnun, 2012). Keberhasilan proses belajar mengajar merupakan hal utama yang diharapkan dalam melaksanakan pendidikan di sekolah (Gayatri et al., 2017). Belajar juga dimaknai sebagai proses perubahan tingkah laku sebagai akibat adanya interaksi antara individu dengan lingkungannya. Tingkah laku itu mencakup aspek pengetahuan, keterampilan, dan sikap (Ansori (IKIP Siliwangi) \& Samsudin, 2013). Dalam belajar, siswa mengalami sendiri proses dari tidak tahu menjadi tahu (Slameto, 2019). Belajar juga merupakan proses melihat, mengamati, dan memahami sesuatu (Yanuarti \& Rusman, 2019).

Media pembelajaran diharapkan mampu menghilangkan kebosanan dan kejenuhan siswa dalam belajar, sehingga siswa lebih tertarik dan berkonsentrasi dalam pembelajaran. Media pembelajaran mempunyai peran yang penting dalam proses belajar mengajar, karena dapat membuat suasana belajar menjadi lebih hidup dan bermakna (Maimunah, 2016). Interaksi antara guru dan siswa tidak hanya dapat dilakukan melalui hubungan tatap muka secara langsung, akan tetapi dapat juga melalui media pembelajaran. Dalam hal ini, teknologi dan media juga berperan sebagai pengganti guru dalam menyampaikan materi di dalam kelas. Selain itu, belajar merupakan proses bagi 
siswa dalam membangun gagasan atau pemahaman sendiri (Rahmayanti, 2016). Selain itu, penggunaan media pembelajaran dapat membantu mengatasi kesulitan belajar siswa dalam memahami materi yang bersifat abstrak sehingga akan lebih mudah diterima dan dipahami oleh siswa (Handayani et al., 2019).

Video merupakan media elektronik yang mampu menggabungkan teknologi audio dan visual secara bersama sehingga menghasilkan suatu tayangan yang dinamis dan menarik serta mampu menyajikan urutan gambar dalam bentuk gerak secara elektronik (Yudianto, 2017) dan (Munir, 2020). Video pembelajaran adalah media yang cocok untuk pembelajaran pada individu, kelompok kecil, dan kelompok besar di kelas. Fakta ini tidak dapat dilepaskan dari kondisi para siswa saat ini yang tumbuh dan berkembang dalam dunia digital seperti televisi, komputer, laptop, dan android yang sifatnya audio visual dengan menayangkan program yang berbeda (Busyaeri et al., 2016). Dengan adanya penayangan video, siswa dapat merasa seolah-olah mereka berada atau turut serta dalam suasana yang digambarkan. Selain itu, penggunaan video sebagai media pembelajaran dapat diterapkan di berbagai bidang ilmu pengetahuan, salah satunya ilmu kimia. IImu kimia merupakan salah satu mata pelajaran yang sangat penting karena erat kaitannya dengan lingkungan dan kehidupan seharihari. Ilmu kimia adalah bagian dari ilmu pengetahuan alam yang membahas tentang struktur, perpindahan atau perubahan bentuk dan energetika zat. Untuk mempelajari ilmu kimia di sekolah, diperlukan eksperimen yang tepat (Bahruddin, 2018). Ilmu kimia akan lebih baik bermakna apabila dalam pembelajarannya diberikan gejala-gejala, peristiwa yang nyata dari pada diberikan dalam bentuk konsep teori saja (Muti'ah et al., 2021). Selama ini masih banyak siswa yang mengalami kesulitan dalam memahami dan mengikuti pelajaran kimia disebabkan pada dasarnya dalam mempelajari materi kimia tersebut siswa memerlukan pemahaman konsep yang saling berhubungan secara bermakna di dalam kehidupan sehari-hari bukan hanya dengan hafalan.

Pada saat diwawancarai, guru dan siswa menyatakan bahwa dalam materi kimia, terutama materi asam basa, pembelajaran menjadi lebih bermakna apabila dihubungkan dengan lingkungan dan kehidupan sehari-hari. Siswa dapat melihat dan mengamati langsung fenomena yang terjadi dalam materi asam basa, misalnya dalam penentuan asam basa menggunakan indikator alami dan buatan menggunakan sampel atau ekstrak tanaman yang berasal dari alam. Penggunaan video dalam pembelajaran mampu menarik perhatian, keinginan, minat, dan motivasi siswa dalam belajar. Proses pembelajaran tidak terlepas dari lingkungan sekitar, pembelajaran juga tidak terbatas pada ruang kelas saja. Saat ini, dalam kegiatan pembelajaran, guru belum terbiasa menggunakan media pembelajaran yang mampu menarik perhatian siswa. Pembelajaran cenderung monoton karena hanya dititikberatkan pada penguasaan bidang materi pelajaran, sedangkan penambahan di bidang pengalaman tidak terpenuhi. Integrasi lingkungan dalam pembelajaran mampu menghilangkan kejenuhan siswa dalam belajar dan menciptakan siswa yang cinta lingkungan. Pembelajaran berbasis lingkungan adalah pembelajaran yang menekankan lingkungan sebagai media atau sumber belajar (Wuryastuti \& Ima, 2013). Dengan pembelajaran menggunakan Media Video Berbasis Lingkungan (MVBL), siswa mendapatkan pengalaman belajar untuk lebih memahami manfaat ciptaan Tuhan bagi kehidupan, diri, dan keluarganya (Anantasari et al., 2015). Dampak positif dari diterapkannya media berbasis lingkungan adalah bahwa keingintahuan siswa terhadap lingkungannya menjadi bertambah.

Model Pengembangan Four- $D$ merupakan salah satu model desain pembelajaran sistematik (Trianto, 2014). Model Four-D tersusun secara terprogram dan sistematis dengan tujuan memecahkan 
masalah terkait sumber belajar yang disesuaikan dengan kebutuhan dan karakteristik siswa (Arywiantari et al., 2015).

Pada saat proses pembelajaran kimia di sekolah, masih sering dijumpai permasalahan baik secara metode, media, maupun faktor lain seperti motivasi yang rendah, dan kesulitan siswa dalam memahami konsep materi yang bersifat abstrak (Gusti et al., 2017). Berdasarkan hasil wawancara dengan salah satu guru mata pelajaran Kimia di SMAN 03 Bengkulu Utara, diketahui bahwa media pembelajaran yang digunakan hanya buku teks. Namun demikian, buku teks hanya dipinjamkan pada saat pembelajaran kimia berlangsung, sehingga sumber belajar siswa masih kurang. Media buku teks juga memiliki beberapa kelemahan, yaitu tidak bewarna, sangat tebal, serta monoton dan membosankan untuk dibaca. Untuk belajar, siswa hanya bergantung pada penjelasan dan latihan soal dari guru. Hal ini menghambat siswa untuk belajar secara mandiri baik di sekolah maupun di rumah. Fasilitas proyektor di sekolah juga sudah ada, tetapi belum digunakan secara maksimal.

Data hasil evaluasi belajar siswa di SMAN 03 Bengkulu Utara pada mata pelajaran Kimia yang dapat dilihat dari nilai Ulangan Harian (UH) Kimia pada semester genap memperlihatkan persentase yang besar untuk siswa kelas XI IPA yang belum mencapai Kriteria Ketuntasan Minimal (KKM). Untuk SMAN 03 Bengkulu Utara, nilai siswa dianggap tuntas jika memperoleh nilai 75. Adapun distribusi persentase nilai Kimia siswa pada semester genap tersajikan dalam Tabel 1 berikut ini.

Tabel 1 Persentase Nilai Siswa Kelas XI IPA 1 - XI IPA 4 SMAN 03 Bengkulu Utara Berdasarkan Nilai KKM (\%)

\begin{tabular}{cccc}
\hline Materi & TL KKM P KKM L KKM \\
\hline Asam Basa & 27,01 & 39,27 & 33,72 \\
\hline Hidrolisis & 27,93 & 32,35 & 39,72 \\
\hline $\begin{array}{c}\text { Larutan Penxangaa } \\
\text { Kelarutan dan Hasil }\end{array}$ & 27,48 & 31,68 & 40,84 \\
$\begin{array}{c}\text { Kali Kelarutan } \\
\text { Kal Kolad }\end{array}$ & 31,89 & 42,26 \\
\hline Koloid & 26,31 & 18,59 & 55,10 \\
\hline
\end{tabular}

Keterangan :

TL KKM = Tidak lulus KKM

$P K K M=P$ as KKM

$\mathrm{L} K K M=$ Lulus $\mathrm{KKM}$

Berdasarkan Tabel 1, dapat dilihat bahwa persentase siswa masih banyak yang pas KKM bahkan tidak lulus KKM, terutama pada materi asam basa. Terlihat bahwa persentase siswa yang lulus KKM hanya $33,72 \%$ siswa. Angka ini merupakan persentase lulus KKM terkecil jika dibandingkan dengan materi lainnya. Padahal pemahaman konsep materi asam basa di dalam kehidupan sehari-hari secara tidak langsung sudah sering kita gunakan tetapi tidak difokuskan pada siswa. Pemahaman konsep adalah kompetensi dalam menjelaskan keterkaitan antarkonsep, mengaplikasikan konsep secara efisien, luwes, akurat, dan tepat dalam suatu pemecahan masalah (Rahayuningsih, 2018). Pemahaman konsep dalam Permendikbud (2014) dilihat dari kemampuan siswa dalam 1) menyatakan ulang konsep yang telah dipelajari; 2) mengklasifikasikan objek-objek berdasarkan dipenuhi tidaknya persyaratan yang membentuk konsep tersebut; dan 3) menerapkan konsep secara logis. Supaya siswa menjadi tahu dan tertarik untuk mempelajari materi asam basa, diperlukan sebuah media pembelajaran yang melibatkan keterkaitan dalam kehidupan sehari-hari. Salah satu media pembelajaran yang dapat dijadikan alternatif adalah media video pembelajaran berbasis lingkungan. Video pembelajaran berbasis lingkungan merupakan suatu bentuk media pembelajaran yang menggunakan objek belajar dari pengamatan langsung, menggunakan bahan-bahan yang ada di lingkungan sekitarnya sehingga siswa dapat belajar secara mandiri ataupun berkelompok. Video pembelajaran berbasis lingkungan ini sangat diperlukan bagi guru dan siswa agar pembelajaran menjadi lebih bermakna, sehingga materi asam basa menjadi lebih mudah diserap oleh siswa.

Berdasarkan latar belakang di atas, perlu dilakukan penelitian tentang pengembangan 
media video pembelajaran di sekolah supaya dapat memberikan banyak dampak positif dalam penggunaannya, dan memudahkan guru dalam menyampaikan bahan ajar kepada siswa. Rumusan masalah pada penelitian ini adalah: 1) bagaimana kelayakan video pembelajaran berbasis lingkungan untuk materi asam basa sebagai sumber belajar siswa kelas XI IPA di SMAN 03 Bengkulu Utara? dan 2) bagaimana pemahaman konsep siswa kelas XI IPA terhadap video asam basa berbasis lingkungan?. Tujuan yang ingin dicapai pada penelitian ini adalah menghasilkan video pembelajaran berbasis lingkungan untuk materi asam basa yang layak digunakan sebagai sumber belajar serta mengukur pemahaman konsep siswa untuk materi asam basa kelas XI IPA di SMAN 03 Bengkulu Utara. Bagi guru Kimia, penelitian ini diharapkan mampu dijadikan sebagai salah satu ide yang dapat digunakan untuk mengoptimalkan kualitas pembelajaran Kimia melalui pemanfaatan media video pembelajaran berbasis lingkungan. Bagi sekolah, penelitian ini dapat digunakan untuk memberikan informasi yang bersifat ilmiah dan nyata melalui praktik dalam kehidupan sehari-hari dan sebagai pertimbangan untuk memperbarui sarana dan prasarana belajar dalam menunjang peningkatan prestasi belajar siswa.

\section{METODE}

Penelitian ini merupakan penelitian research and devolepment (R\&D). Dalam penelitian ini, produk yang dikembangkan adalah video pembelajaran berbasis lingkungan pada materi asam basa dalam kehidupan sehari-hari untuk siswa kelas XI IPA SMAN 03 Bengkulu Utara. Populasi dalam penelitian ini adalah seluruh siswa kelas XI IPA SMAN 03 Bengkulu Utara yang terdiri atas empat kelas. Pemilihan kelas sampel dalam penelitian ini dilakukan secara random yang didapat dari uji normalitas, yaitu kelas XI IPA 2 dan XI IPA 3.

Prosedur penelitian ini dilakukan dengan mengembangkan media video pembelajaran yang menggunakan model 4D dengan tahapan model yang digunakan dalam pengembangan yaitu model 4D yang di dalamnya terdapat beberapa tahapan define, design, develop, and disseminate (Solikin \& Amalia, 2019). Akan tetapi, dalam penelitian ini hanya dilakukan sampai tahapan 3D. Berikut dijelaskan secara rinci langkahlangkah pengembangan video pembelajaran menggunakan model sampai tahapan 3D adalah sebagai berikut.

\section{Define (Pendefinisian)}

Tahap define (pendefinisian) dilakukan melalui analisis awal yang bertujuan untuk memunculkan dan menetapkan masalah yang dihadapi dalam pembelajaran sehingga dibutuhkan pengembangan bahan pembelajaran. Perangkat pembelajaran dibuat berdasarkan identifikasi analisis awal yang telah dilakukan. Pada tahap ini pula, guru melakukan diagnosis awal untuk meningkatkan efisiensi dan efektivitas pembelajaran serta menetapkan kompetensi yang akan dikembangkan oleh peneliti. Analisis siswa, dilakukan untuk mengetahui karakteristik siswa dilihat dari kemampuan, sumber belajar, motivasi belajar, latar belakang pengalaman, dan sebagainya. Analisis konsep, dilakukan dengan cara mengidentifikasi materi, memilih materi yang relevan dan menyusun kembali secara sistematis. Analisis tugas, merupakan kumpulan prosedur untuk menentukan isi dalam satuan pembelajaran. Dalam hal pembelajaran, guru menganalisis tugastugas pokok yang harus dikuasai siswa agar siswa dapat mencapai kompetensi minimal. Analisis tugas dilakukan untuk memerinci isi materi ajar dalam bentuk garis besar. Analisis tujuan pembelajaran, yaitu kegiatan merangkum hasil dari analisis konsep dan analisis tugas untuk menentukan tujuan pembelajaran. Tujuan pembelajaran inilah yang digunakan dalam pengembangan video pada materi asam basa sebagai media pembelajaran. 


\section{Design (Perancangan)}

Pada tahap ini, peneliti membuat rancangan awal (prototype) atau rancangan produk yang sudah disesuaikan dengan kerangka isi hasil analisis awal, analisis siswa, analisis konsep, analisis tugas, dan spesifikasi tujuan.

\section{Development (Pengembangan)}

Tahap ini dilakukan dengan cara menguji isi sumber belajar kepada ahli yang terlibat pada saat validasi rancangan dan siswa yang menggunakan sumber belajar tersebut. Instrumen penelitian pada penelitian ini adalah instrumen lembar validasi, instrumen uji coba produk, dan instrumen tes. Pilihan jawaban dan skor untuk lembar validasi mengacu pada skala Likert dengan kriteria respons yang memiliki skor 1 sampai dengan 5 dengan ketentuan bahwa skor 1 menunjukan jawaban sangat tidak setuju, skor 2 menunjukan jawaban tidak setuju, skor 3 menunjukan jawaban kurang setuju, skor 4 menunjukan jawaban setuju dan skor 5 menunjukan jawaban sangat setuju. Teknik analisis data yang digunakan adalah uji normalitas, analisis validitas, analisis uji coba produk dan analisis tes.

\section{HASIL DAN PEMBAHASAN}

\section{A. Kelayakan Video Pembelajaran Berbasis Lingkungan untuk Materi Asam Basa}

Penelitian dan pengembangan ini dilaksanakan di SMA Negeri 03 Bengkulu Utara. Populasi dalam penelitian ini adalah siswa kelas XI IPA sebanyak 4 kelas yang berjumlah 100 siswa. Dari populasi tersebut, dilakukan uji normalitas untuk menentukan kelas sampel yang bersifat normal. Dari seluruh kelas yang telah diujinormalitasnya, ditentukan sampel dengan cara random sampling sebanyak 2 kelas, sehingga didapatkan kelas XI IPA 4 sebagai kelas skala kecil dan kelas XI IPA 1 sebagai kelas skala besar.

Tahap pengembangan produk dilakukan dengan menggunakan model 4-D, tetapi dilaksanakan hanya sampai tahapan 3-D.

\section{Pendefinisian (Define)}

Dari tahap pendefinisian (define) pada mata pelajaran Kimia di SMAN 03 Bengkulu Utara diperoleh data berupa analisis awal, analisis karakteristik siswa, analisis konsep, analisis tugas, dan spesifikasi tujuan pembelajaran. Proses tahapan tersebut dapat dideskripsikan sebagai berikut.

\section{a. Analisis Awal}

Pada tahap awal ini dilakukan wawancara terhadap salah satu guru mata pelajaran Kimia di SMAN 03 Bengkulu Utara. Ditemukan masalah dalam proses pembelajaran, di antaranya adalah pemahaman siswa terhadap konsep materi kimia yang bersifat menghapal, serta siswa kurang termotivasi untuk belajar sehingga hasil belajar kimia pun kurang maksimal.

\section{b. Analisis Siswa}

Pada tahap analisis ini didapatkan hasil observasi siswa. siswa di SMAN 03 Bengkulu Utara khususnya kelas XI IPA memiliki respons pasif. Sebagian siswa tidak antusias dalam mengikuti kegiatan pembelajaran. Siswa tersebut tidak fokus pada materi yang disampaikan guru. Mereka cenderung aktif dengan keperluan di luar mata pelajaran Kimia, seperti sibuk mengobrol dengan teman sebangkunya. Siswa juga ada yang terlihat melihat jam dinding, bahkan ada salah satu siswa yang menguap berkali-kali. Ditinjau dari hasil belajar siswa pada mata pelajaran Kimia, masih banyak siswa yang belum mencapai nilai Kriteria Ketuntasan Minimal (KKM). Berdasarkan hasil wawancara dengan siswa kelas XI IPA di SMAN 03 Bengkulu Utara, terdapat beberapa siswa yang menyatakan sulit dalam memahami konsep yang terdapat dalam buku teks yang disediakan oleh pihak sekolah. Oleh karena itu, siswa menginginkan media pembelajaran yang menarik dan menuntun siswa dalam proses pembelajaran, baik secara individu maupun berkelompok. 


\section{c. Analisis Konsep}

Materi yang diterapkan dalam penelitian ini adalah materi asam basa karena dari persentase nilai siswa kelas XI IPA 1 - XI IPA 4 di SMAN 03 Bengkulu Utara hanya 33,72\% siswa yang lulus KKM. Angka ini merupakan persentase terkecil dibandingkan dengan materi yang lainnya. Setelah memilih materi, langkah selanjutnya adalah menganalisis silabus untuk mengetahui kompetensi inti dan kompetensi dasar, kemudian mengumpulkan bahan ajar yang dapat digunakan dalam penyusunan media pembelajaran, seperti buku pegangan guru di kelas XI untuk SMA/ MA Kurikulum 2013.

\section{d. Analisis Tugas}

Pada tahap analisis tugas, langkah awal yang dilakukan adalah menganalisis keterampilan-keterampilan yang akan dikaji dengan membuat rincian isi materi ajar secara garis besar. Analisis tugas mencakup analisis struktur isi materi yang ingin disampaikan dalam media video pembelajaran untuk materi asam basa. Penelitian ini difokuskan pada pengembangan media video pembelajaran berbasis lingkungan.

\section{e. Spesifikasi Tujuan Pembelajaran}

Pada tahap ini, kegiatan yang dilakukan peneliti adalah merangkum hasil dari analisis konsep dan analisis tugas untuk menentukan tujuan pembelajaran dalam penelitian dengan cara menyusun dan merancang media video pembelajaran.

\section{Perancangan (Design)}

Setelah tahap define, tahap selanjutnya adalah tahap designatau tahap perancangan. Dalam tahap perancangan ini ada tiga langkah, yaitu penyusunan kisi-kisi angket dan tes, pemilihan media, serta desain awal media pembelajaran.

Pada tahap ini juga ditentukan background dan backsound yang digunakan. Adapun uraiannya adalah sebagai berikut:

a. Background pada tampilan interface dalam media video pembelajaran berbasis lingkungan yang digunakan peneliti background hijau, dan setiap materi didesain dengan background warna putih dan hitam. Adapun jenis huruf yang digunakan untuk mendesain teks adalah arial dengan ukuran 11 untuk materi asam basa.

b. Backsound pada media ini menggunakan instrumen musik Heroes Tonight yang santai, tetapi ceria. Rancangan awal media video pembelajaran yang telah direvisi berdasarkan masukan dari validator ahli materi selanjutnya diujicobakan pada tahap pengembangan.

Adapun software yang dipilih untuk mendesain berbagai komponen tersebut adalah Adobe Premiere Pro. Software tersebut dipilih karena memiliki berbagai macam fitur yang lengkap untuk mendesain media, seperti timeline yang dapat diisi dengan banyak sekali video serta audio untuk memperkaya efek sehingga video yang dihasilkan berkualitas baik.

\section{Pengembangan (Develop)}

a. Penilaian Kelayakan Produk

Kelayakan produk pengembangan media video pembelajaran berbasis lingkungan dinilai oleh tiga orang ahli (validator) yang terdiri atas satu orang ahli media dan dua orang ahli materi.

Validasi menilai media video pembelajaran ini dilakukan oleh dosen Universitas Bengkulu yang ahli di bidang media. Berikut ini adalah hasil penilaian oleh ahli media yang disajikan dalam Tabel 2 .

Tabel 2 Hasil Persentase Validasi oleh Ahli Media

\begin{tabular}{ccc}
\hline $\begin{array}{c}\text { Persentase } \\
\text { Skor }\end{array}$ & Kriteria & Keterangan \\
\hline $93 \%$ & Sangat Valid & $\begin{array}{c}\text { Tidak Perlu } \\
\text { Revisi }\end{array}$ \\
\hline
\end{tabular}

Hasil penilaian oleh ahli media menunjukkan nilai persentase sebesar $93 \%$ dengan kriteria "sangat valid" dan tidak perlu revisi. Dengan demikian, kelayakan produk media video pembelajaran berbasis 
lingkungan dengan materi asam basa sudah layak dijadikan media pembelajaran di sekolah.

Ahli materi yang menilai materi pada media video pembelajaran berbasis lingkungan adalah dosen Pendidikan Kimia di Universitas Bengkulu dan salah satu guru Kimia di SMA Negeri 03 Bengkulu Utara. Hasil persentase rata-rata penilaian ahli materi disajikan pada Tabel 3.

Tabel 3 Hasil Persentase Rata-Rata Penilaian Ahli Materi

\begin{tabular}{lll}
\hline Analisis & \multicolumn{2}{l}{ Validator } \\
\cline { 2 - 3 } & V1 (Dosen) & V2 (Guru) \\
\hline $\begin{array}{l}\text { Skor } \\
\text { Persentase }\end{array}$ & $71,42 \%$ & $88,57 \%$ \\
\hline $\begin{array}{l}\text { Persentase } \\
\text { Rata-Rata }\end{array}$ & \multicolumn{2}{c}{$79,99 \%$} \\
\hline Kriteria & "Valid dan layak, perlu \\
& sedikit revisi" & \\
\hline
\end{tabular}

Berdasarkan hasil validasi oleh ahli materi pada Tabel 3, diketahui bahwa hasil persentase rata-rata dari kedua validator tersebut adalah 79,99\% dengan kriteria "valid dan layak, perlu sedikit revisi". Perbaikan pada materi asam basa dalam media video pembelajaran berbasis lingkungan dapat dilihat pula pada Tabel 4 .

Tabel 4 Daftar Revisi Ahli Materi

\begin{tabular}{|c|c|}
\hline Daftar Revisi & Jindak Lanjut \\
\hline $\begin{array}{l}\text { Sebaiknya pada } \\
\text { informasi pendukung } \\
\text { ditambah lagi materi. }\end{array}$ & $\begin{array}{l}\text { Materi sudah } \\
\text { ditambahkan dari } \\
\text { informasi pendukung } \\
\text { dengan mengambil } \\
\text { dari referensi yang } \\
\text { update. }\end{array}$ \\
\hline $\begin{array}{l}\text { Tampilan video kurang } \\
\text { menarik cenderung } \\
\text { membosankan. }\end{array}$ & $\begin{array}{l}\text { Mengubah tampilan } \\
\text { pada video. }\end{array}$ \\
\hline $\begin{array}{l}\text { Pada kesimpulan suara } \\
\text { narator dalam video } \\
\text { pembelajaran kurang } \\
\text { jelas dan terlalu } \\
\text { panjiang. }\end{array}$ & $\begin{array}{l}\text { Mengganti suara } \\
\text { narator di bagian } \\
\text { kesimpulan dengaan. } \\
\text { suara yang lebih } \\
\text { jelas, terstruktur, } \\
\text { padat, dan singkat }\end{array}$ \\
\hline
\end{tabular}

b. Uji Coba Produk

Produk diujicobakan dengan uji coba skala kecil yang terdiri atas 12 siswa kelas $\mathrm{XI}$ IPA 4, sedangkan uji coba skala besar terdiri atas 25 siswa pada kelas XI IPA 1. Uji coba dalam pengembangan produk merupakan salah satu aktivitas penting yang tujuannya adalah untuk mencari sebanyak-banyaknya kesalahan, error, ataupun defect (Tasri, 2011). Hasil dari uji coba produk media video pembelajaran berbasis lingkungan dikategorikan kelayakannya berdasarkan skala Likert. Adapun hasil uji coba produk dapat dilihat pada Tabel 5.

Tabel 5. Hasil Uji Coba Produk Media Video Pembelajaran

\begin{tabular}{cccc}
\hline \multirow{2}{*}{ No. } & \multirow{2}{*}{ Uji Coba } & \multicolumn{2}{c}{ Hasil Analisis } \\
\cline { 3 - 4 } & Uji Coba & $X$ & Kriteria \\
\hline 1 & Skala Kecil & $92,13 \%$ & $\begin{array}{c}\text { Sangat Setuju, } \\
\text { Sangat Layak }\end{array}$ \\
\hline 2 & $\begin{array}{c}\text { Uji Coba } \\
\text { Skala Besar }\end{array}$ & $92,2 \%$ & $\begin{array}{c}\text { Sangat Setuju, } \\
\text { Sanqat Lavak }\end{array}$ \\
\hline
\end{tabular}

Berdasarkan Tabel 5, diketahui bahwa kelayakan media video pembelajaran berbasis lingkungan dengan uji coba skala kecil mendapatkan skor persentase ratarata $92,13 \%$ dan uji coba skala besar adalah $92,2 \%$ dengan kriteria bahwa siswa sangat setuju dengan video asam basa berbasis lingkungan sebagai sumber belajar. Hasil uji coba produk pada kelompok skala besar yang mencapai persentase ratarata sebesar $90,90 \%$ termasuk kualifikasi sangat layak. Dengan media pembelajaran ini, siswa mudah menyimpulkan bagian dari materi dengan melihat ilustrasi-ilustrasi yang ada dan simulasi-simulasi yang disajikan dalam media pembelajaran yang membantu peserta didik untuk memahami konsep dari materi. Video pembelajaran disajikan terintegrasi dengan lingkungan pada materi asam basa sebagai uapaya untuk memberikan pemahaman kepada siswa tentang konsep materi asam basa dengan potensi alam yang sering digunakan dalam kehidupan sehari-hari. Harapannya adalah siswa tidak lagi beranggapan bahwa materi kimia itu sulit yaitu hanya membahas rumus, hitungan, dan reaksi-reaksi kimia, akan tetapi konsep ilmu kimia langsung dapat diterapkan dalam kehidupan sehari-hari. 
Sesuai dengan penelitian sebelumnya, penggunaan media pembelajaran dalam proses belajar mengajar dapat membangkitkan minat, keinginan, motivasi, dan bahkan membawa pengaruh-pengaruh psikologis terhadap pebelajar (Falahudin, 2017). Oleh karena itu, video asam basa berbasis lingkungan dapat menjadi alternatif sebagai media pembelajaran bagi siswa untuk mengatasi kejenuhan pada saat pembelajaran dengan buku teks. Dengan menggunakan media audiovisual, pembelajaran menjadi aktif, konkret, menarik, dan efektif sehingga dapat meningkatkan hasil belajar.

\section{B. Uji Pemahaman Konsep Siswa pada Media Video Asam Basa Berbasis Lingkungan \\ Uji pemahaman konsep siswa dilakukan} pada kelas skala besar, yaitu kelas XI IPA 2. Dari hasil uji pemahaman pada 25 siswa, terdapat 23 siswa yang menunjukkan lulus KKM dan 2 siswa nilai uji pemahamannya tidak lulus KKM. Adapun distribusi persentase hasil rata-rata test pemahaman siswa untuk materi asam basa disajikan dalam Tabel 6 .

Tabel 6 Persentase Nilai Hasil Tes Pemahaman Konsep Siswa

\begin{tabular}{cccccc}
\hline Kelas & Media & Materi & $\begin{array}{c}\text { TL } \\
\text { KKM }\end{array}$ & $\begin{array}{c}\text { L } \\
\text { KKM }\end{array}$ & $\begin{array}{c}\text { Persentase } \\
\text { Nilai Rata- } \\
\text { Rata }\end{array}$ \\
\hline $\begin{array}{c}\text { XI } \\
\text { IPA 1 }\end{array}$ & Video & $\begin{array}{c}\text { Asam } \\
\text { Basa }\end{array}$ & $8 \%$ & $92 \%$ & $88,8 \%$ \\
\hline
\end{tabular}

Berdasarkan Tabel 6, nilai pemahaman konsep pada media video pembelajaran untuk materi asam basa yang tidak lulus KKM hanya $8 \%$, siswa yang lulus KKM sebanyak $92 \%$, dan hasil persentase nilai rata-rata siswa berdasarkan nilai pemahaman konsep materi asam basa adalah sebesar 88,8 $\%$. Kriteria nilai pemahaman siswa yang berkisar antara $76 \%-100 \%$ tergolong baik sekali. Penggunaan video pembelajaran memengaruhi hasil belajar siswa. Hal ini sesuai dengan penelitian sebelumnya yang menyatakan bahwa semakin baik dan bervariasinya metode pembelajaran, media pembelajaran, dan sumber belajar yang diterapkan, capaian standar kompetensi lulusan akan semakin baik (Alperi \& Handayani, 2019).

Hal ini juga menunjukan bahwa video asam basa berbasis lingkungan dapat dijadikan alternatif bantuan bagi siswa agar memahami konsep asam basa dengan baik. Hasil penelitian yang didapatkan adalah sesuai dengan hasil penelitian sebelumnya yaitu penggunaan media video efektif digunakan dalam pembelajaran untuk meningkatkan pemahaman konsep siswa (Ningsih, 2016). Sajian audiovisual atau lebih dikenal dengan multimedia dapat dimanfaatkan untuk mewujudnyatakan sesuatu yang abstrak. Stimulus visual mempunyai efek yang baik terhadap hasil belajar siswa pada tugas seperti fase mengingat, mengenali, mengingat kembali, dan menghubungkan fakta dan konsep (Fahmi, 2014). Selain itu, media yang sesuai dengan abad ke-21 dan sangat disenangi oleh siswa adalah media berbasis komputer karena lebih menarik tampilannya (Alperi, 2020).

Beberapa kelebihan video asam basa berbasis lingkungan ini adalah 1) tampilan media video pembelajaran menarik dan tidak membosankan karena dapat memperjelas hal-hal yang abstrak dan memberikan penjelasan yang lebih realistik; 2) video asam basa berbasis lingkungan ini dalam pengoperasiannya cukup mudah karena dapat diakses di aplikasi Youtube melalui laptop ataupun smartphone sehingga memudahkan siswa dalam belajar secara mandiri baik di sekolah maupun di rumah tanpa dibatasi ruang dan waktu; 3) penggunaan video pembelajaran berbasis lingkungan yang disertai animasi ini juga dapat mengembangkan kemampuan berpikir dan mengemukakan pendapat siswa; dan 4) video pembelajaran dapat diakses secara offline dengan menggunakan flashdisk, $C D$, ataupun menggunakan bluetooth. 


\section{SIMPULAN DAN SARAN}

\section{Simpulan}

Dari hasil penelitian, dapat disimpulkan bahwa video asam basa berbasis lingkungan untuk siswa kelas XI IPA di SMA 03 Bengkulu Utara ini sangat layak digunakan sebagai sumber belajar. Hal ini ditunjukkan dari hasil validator ahli media dan materi yang menyatakan bahwa media sangat layak untuk digunakan. Selain itu terjadi peningkatan pemahaman konsep siswa setelah diberikan media video pembelajaran berbasis lingkungan dengan perolehan nilai terendah 65 dan nilai tertinggi 100 dengan persentase nilai rata-rata adalah $88,8 \%$, yang tergolong kategori baik sekali.

\section{Saran}

Untuk peneliti selanjutnya, sebaiknya penggunaan model 4D (Four $D$ ) dilakukan sampai tahapan disseminate. Selain itu, dilakukan penyebaran media video pembelajaran berbasis lingkungan ke sekolah-sekolah lainnya supaya media video pembelajaran berbasis lingkungan ini diketahui oleh guru-guru Kimia lainnya agar dapat diaplikasikan dalam proses belajar mengajar dan tidak hanya dapat diakses oleh siswa di SMAN 03 Bengkulu Utara.

Untuk guru, dalam pengerjaan soal tes pemahaman bagi siswa diharapkan jumlah soal disesuaikan dengan waktu yang di sediakan, sehingga dapat diperoleh hasil yang lebih maksimal.

Untuk sekolah, hasil penelitian ini dapat digunakan untuk memberikan informasi yang bersifat ilmiah dan nyata melalui praktik dalam kehidupan sehari-hari dan sebagai pertimbangan untuk memperbarui sarana dan prasarana belajar dalam menunjang peningkatan prestasi belajar siswa.

\section{PUSTAKA ACUAN}

Alperi, M. (2020). PERAN BAHAN AJAR DIGITAL SIGIL DALAM MEMPERSIAPKAN KEMANDIRIAN BELAJAR PESERTA DIDIK. Jurnal Teknodik. https://doi.org/10.32550/ teknodik.v0i1.479
Alperi, M., \& Handayani, D. (2019). Quality Mapping Analysis of Methods, Media and Learning Resources Usage at Junior High School. https://doi.org/10.2991/ icetep-18.2019.76

Anantasari, W., Jufri, A. W., \& Hadiwijaya, A. S. (2015). EFEKTIFITAS PENGGUNAAN MEDIA VIDEO BERBASIS LINGKUNGAN (MVBL) DALAMMENINGKATKAN PERILAKU POSITIF ANAK TERHADAP LINGKUNGAN. Jurnal Penelitian Pendidikan IPA, 1(1). https://doi. org/10.29303/jppipa.v1i1.5

Ansori (IKIP Siliwangi), \& Samsudin, A. (IKIP S. (2013). Transformasi Pembelajaran di Pendidikan Non Formal. EMPOWERMENT, 2(1).

Arywiantari, D., Agung, A. . G., \& Tastra, I. D. K. (2015). Pengembangan multimedia interaktif pada pembelajaran IPA di SMP Negeri 2 singaraja. Jurnal Edutech Universitas Pendidikan Ganesha, 3(1).

Bahruddin, B. (2018). Dampak Pembelajaran Eksperimen Kimia Terhadap Minat dan Hasil Belajar Siswa. Andragogi: Jurnal Diklat Teknis Pendidikan Dan Keagamaan, 6(1). https://doi. org/10.36052/andragogi.v6i1.45

Busyaeri, A., Udin, T., \& Zaenudin, A. (2016). PENGARUH PENGGUNAAN VIDEO PEMBELAJARAN TERHADAP PENINGKATAN HASIL BELAJAR MAPEL IPA DI MIN KROYA CIREBON. Al Ibtida: Jurnal Pendidikan Guru MI, 3(1). https://doi.org/10.24235/al.ibtida. snj.v3i1.584

Fahmi, S. \& M. (2014). Pengembangan Multimedia Macromedia Flash dengan Pendekatan Kontekstual dan Keefektifannya terhadap Sikap Siswa pada Matematika Developing Multimedia Macromedia Flash with Contextual Approach and Its Effect on Students 'Attitude toward Mathematics. PYTHAGORAS: Jurnal Pendidikan Matematika, 9(1), 90-98. https://journal. uny.ac.id/index.php/pythagoras/article/ view/9071 
Falahudin, I. (2017). Pemanfaatan Media dalam Pembelajaran Iwan. In Diponegoro Medical Journal (Jurnal Kedokteran Diponegoro) (Vol. 6, Issue 2).

Gayatri, E. R. P., Bahar, A., \& Handayani, D. (2017). PERBANDINGAN PENERAPAN MODEL PEMBELAJARAN LEARNING CYCLE (5E) DAN TWO STAY TWO STRAY. Alotrop, 1(1). https://doi. org/10.33369/atp.v1i1.2726

Gusti, N., Bahar, A., \& Handayani, D. (2017). STUDI PERBANDINGAN PEMBELAJARAN KOOPERATIF MENGGUNAKAN MEDIA CHEMICAL DOMINO CARD DAN FLASH CARD. Alotrop, 1(2). https://doi.org/10.33369/ atp.v1i2.3507

Handayani, D., Sundaryono, A., \& Rohiat, S. (2019). Think Pair Share Cooperative Learning Model Using Edmodo Application. https://doi.org/10.2991/aes18.2019 .60

Inanna, I. (2018). PERAN PENDIDIKAN DALAM MEMBANGUN KARAKTER BANGSA YANG BERMORAL. JEKPEND: Jurnal Ekonomi Dan Pendidikan, 1(1). https://doi. org/10.26858/jekpend.v1i1.5057

Mahnun, N. (2012). Media Pembelajaran (Kajian terhadap Langkah-langkah Pemilihan Media dan Implementasinya dalam Pembelajaran). An-Nida', 37(1).

Maimunah, M. (2016). METODE PENGGUNAAN MEDIA PEMBELAJARAN. Al-Afkar: Jurnal Keislaman \& Peradaban, 5(1). https:// doi.org/10.28944/afkar.v5i1.107

Munir. (2020). Multimedia Konsep \& Aplikasi Dalam Pendidikan. In Antimicrobial agents and chemotherapy (Vol. 58, Issue 12).

Muti'ah, M., Siahaan, J., \& Sukib, S. (2021). Upaya Meningkatkan Motivasi dan Pemahaman IImu Kimia Melalui Demonstrasi Kimia Bagi Siswa SMA N
1 Labuapi. Jurnal Pengabdian Magister Pendidikan IPA, 4(2). https://doi. org/10.29303/jpmpi.v4i2.704

Ningsih, Y. L. (2016). Kemampuan Pemahaman Konsep Matematika Mahasiswa Melalui Penerapan Lembar Aktivitas Mahasiswa (LAM) Berbasis Teori APOS Pada Materi Turunan. Edumatica, 6(1).

Rahayuningsih, S. (2018). Pemahaman Konsep Mahasiswa Perempuan dalam Menyelesaikan Masalah Grup. MUST: Journal of Mathematics Education, Science and Technology, 3(1). https:// doi.org/10.30651/must.v3i1.1629

Rahmayanti, V. (2016). Pengaruh Minat Belajar Siswa dan Persepsi atas Upaya Guru dalam Memotivasi Belajar Siswa terhadap Prestasi Belajar Bahasa Indonesia Siswa SMP di Depok. SAP (Susunan Artikel Pendidikan), 1(2). https://doi.org/10.30998/sap.v1i2.1027

Slameto, 2012. (2019). Belajar Dan Faktorfaktor Yang Mempengaruhinya. Jakarta: Rineke Cipta. Journal of Chemical Information and Modeling, 53(9).

Solikin, I., \& Amalia, R. (2019). MATERI DIGITAL BERBASIS WEB MOBILE MENGGUNAKAN MODEL 4D. SISTEMASI, 8(3). https://doi. org/10.32520/stmsi.v8i3.461

Tasri, L. (2011). PENGEMBANGAN BAHAN AJAR BERBASIS WEB. Jurnal MEDTEK, Volume 3.

Trianto. (2014). Media Pembelajaran Terpadu: dalam teori praktek. In Jakarta, Prestasi Pustaka.

Wuryastuti, S., \& Ima, N. (2013). MODEL PEMBELAJARAN BERBASIS LINGKUNGAN UNTUK PEMBUATAN KOMPOR BIOGAS ( Penelitian pada Pembelajaran Mata Kuliah Konsep Dasar Biologi di UPI Kampus Serang ). EduHumaniora | Jurnal Pendidikan Dasar Kampus Cibiru, 5(2). 
Dewi Handayani dkk: Pengembangan Video Asam Basa Berbasis Lingkungan Untuk Meningkatkan Pemahaman Siswa Kelas XI

Yanuarti, R., \& Rusman, R. (2019).

Pemanfaatan teknologi informasi dan komunikasi (TIK) oleh guru di sekolah penerima Universal Service Obligation (USO). Jurnal Penelitian IImu Pendidikan, 11(2). https://doi. org/10.21831/jpipfip.v11i2.19441

Yudianto, A. (2017). Penerapan Video Sebagai Media Pembelajaran. Seminar Nasional Pendidikan 2017. 